\title{
ADAPTING CHRISTIANITY ON THE SIBERIAN EDGE DURING THE EARLY SOVIET PERIOD ${ }^{1}$
}

\author{
Art Leete, Laur Vallikivi
}

\begin{abstract}
The focus of this article is on different adaptations of Christianity by the northern indigenous peoples of Russia in the early Soviet period. We shall examine the community of Yup'ik Eskimo maritime hunters who experimented with Christian ritual forms in order to overcome the crisis caused by the intrusion of the Soviets. Naukan Yup'ik developed a Christian-influenced ritualistic practice to fight back against growing pressure from the Soviets. We propose that the spiritual developments of this community on the edge of Siberia were tightly related to changing economic, social and political conditions.
\end{abstract}

Key words: Christianity, reforms, Soviet period, the North, Yup'ik Eskimo

Early Soviet reforms had predominantly a secular and materialistic character. At the same time, these reforms produced unexpected outcomes in the religious attitudes, ideas and behaviour of the state's population. The intensification of religious feelings as a reaction to the public secular ideology and administrative measures was a common phenomenon from central Russia to the Siberian periphery. It spread amongst different ethnic and social groups from the very beginning of the Soviet period (A Collection 1919). Among others, the radical atheistic turn in Russia also provoked an upsurge of various Protestant groups who acted as conservative, anti-modernist and anti-Communist movements. Significantly, there was a period of mutual imitation between Communists and Protestants that has some importance for our analysis below.

At the beginning of the 1920 s, the competition between secular and spiritual worldviews was developing rapidly in Siberia like everywhere else in Soviet Russia. The main architect of the anti-religious policies, Emelyan Iaroslavskii characterised these processes as a "search for ideological forms". As Iaroslavskii insisted, the poorest were more empathetic towards the anti-religious propaganda (Iaroslavskii 1922: 141-142). This statement is in accordance with the principle of the Communist ideology that envisions the urban and rural proletariat as a leading force in the socialist development. But besides this formal ideological correctness, Iaroslavskii described the real situation of the contemporary religious "front" in Siberia differing considerably from the ideological statements he himself made. 
In this article we examine the remote community of the Yup'ik Eskimos who live in the easternmost corner of the Far East in Chukotka (see Kerttula 2000). Our aim is to bring peripheral events into a wider historical and anthropological context and demonstrate how the introduction of the Soviet regime in the border areas created a certain kind of border management through spiritual options. We rely here on written sources published both in the Soviet Union and elsewhere during the early Soviet period. These sources reflect contradictory perceptions of the situation because of divergent ideological perspectives the participants entertained. In dialogue with the recent anthropological scholarship on the area (see especially Schweitzer \& Golovko 2007), we elaborate some issues we have started to focus upon elsewhere (Leete \& Vallikivi 2011).

Unlike many Siberian groups, most of the Yup'ik remained un-baptised in the tsarist period, as they encountered Christian missionaries infrequently and relatively late. The change of the state regime in 1917 hit (although with delays) not only indigenous communities of Siberia but also missionaries whose activities were destined to stop. If the 1920s was a relatively benign period for some, especially for Protestant missionaries and shamans, from the late 1920s onwards, all religious specialists were effectively silenced, imprisoned or executed by the Soviet state. Since then all religious activists, not only the Orthodox clergy, but also the members of Protestant churches and the shamans were categorized as "the enemies of the people". Proselytizing the ideology of Marxist-Leninist "scientific atheism", the state itself acted as a secular missionary force causing widespread resistance.

The Yup'ik group underwent significant social and religious transformations in the early Soviet period. In one of the Yup'ik communities, a few people started a series of religious innovations in a vaguely Christian style at the beginning of the $1930 \mathrm{~s}$. We are not here going to discuss which category of "movement" these Christian-inspired actions could be classified as (see Leete \& Vallikivi 2011; Schweitzer \& Golovko 2007) or whether the actors could be called Christians (cf. Cannell 2006; Robbins 2009). Instead we will look at the broader field of imitative practices between the Soviets, Christians and the Yup'ik in that period which hopefully helps to capture what was at stake in these economic, political and religious transformations.

One can find little mention about the northern peoples' growing interest in Protestant missions within contemporary Soviet accounts. In 1925, BonchOsmolovskii writes that the American economic, political and cultural impact has had a positive influence on the development of the Chukchis (a term that comprised also then the Naukan Yup'ik). In his depiction, during the tsarist 
period, American missionaries had worked in Chukotka and taught English to the natives. After the Russian Revolution, Americans intensified their missionary activities. Groups of evangelical missionaries (young American men and women) arrived to Chukotka. They presented sermons "in yurtas $\mathrm{s}^{2}$, under the blank sky, on the rocks and boats" and the missionary work was allegedly having some success. The interest of the Chukchis towards America was supported also by stories about the life of the Eskimos, told by persons who had visited Alaska. Bonch-Osmolovskii claims that many Alaskan Eskimos had obtained higher education, had respectable jobs as engineers, medical doctors or lawyers. Alaskan indigenous peoples were represented in the Parliament, a network of schools and medical aid was organised brilliantly. The government supported reindeer herding and dog-keeping generously. His conclusion is unambiguous: "Naturally, our natives feel an attraction towards America. They see that the living standard of their American relatives is higher and everything looks more attractive there" (Bonch-Osmolovskii 1925: 84)3.

Another Soviet author Mel'nikov, who had spent two months among the Chukchis, supported the idea that the American influence had an indisputably positive effect on the indigenous peoples on the Soviet side of the Bering Strait: "What do the Chukchis need? For them, the free trade with the American merchants must be maintained. They get from the Americans all they need for their households. If the Chukchis have a good rifle, they can always find food" (Mel'nikov 1925: 161) .

Before looking at the case of the Yup'ik Eskimos more closely, we shall discuss the mutually defined dynamics of Soviet and Christian imagination and practices. We propose that in the early Soviet period imitative engagement was not only specifically an issue of some indigenous groups on the margins of the empire but was practiced widely across various societal sections. This kind of "institutional mimesis" [mimesis in Taussig's (1993) sense] was a mixture of admiration and accusatory practice between enemies who attempted to avoid yielding to each other. The idea that the borders had to be managed was underlying these relations. From the perspective of some Christian groups, in the early years at least, the revolutionary events were seen to contribute to the Christian evangelization. The soaring numbers of converts were proof of that. From the perspective of the early Bolsheviks, "sectarians" (sektanty) alongside Northern "natives" (tuzemtsy) were semi-acceptable groups as they bore some family resemblance to Communists. These classificatory and border management practices were also something imported to the indigenous communities for whom identity had not been historically an issue of rigid fixedness. 


\section{CHRISTIAN COMMUNISTS OR COMMUNIST CHRISTIANS?}

The Soviet state in its religious policies focussed above all on the Russian Orthodox Church (ROC) because of their tight relationship with the tsarist regime. The ROC was portrayed as the ultimate adversary, the old regime, that spread "the opiate of the masses" and hindered creation of the socialist society. During the New Economic Policy (NEP) years (1921-28), according to the official party line, "anti-religious work was conceived as a long-term educative process rather than as 'destructive and negative"' (Walters 1993: 8). As the hope for sudden conversion to Marxism-Leninism was not realised, leading ideologists became convinced that the uneducated masses had to be re-educated over time. Yet the ROC as an institution needed to be destroyed first. On the one hand, people had to be alienated from the Church as a necessary step to alienate them from their faith. On the other hand, there were material motives at play as these anti-church attacks were strongly motivated by the Bolsheviks' desire for the wealth of the church. By forcibly taking church valuables, the new government aimed to gain twofold (Peris 1998).

In practice, Bolsheviks were considerably inconsistent and divided among themselves over anti-religious policies. While the ROC was being disintegrated, the Old Believers and Protestants enjoyed greater toleration and even occasional support from the authorities. As a result, in the $1920 \mathrm{~s}$, the number of evangelicals (most of them Baptists) increased manifold to the surprise of the revolutionaries. An Old Bolshevik Vladimir Bonch-Bruevich, Lenin's secretary from 1917 until 1920 and a student of the Old Believers, saw in the nonOrthodox a positive force against "the reactionaries". According to him, dissident believers who had suffered during the tsarist regime alongside atheist revolutionaries were using the cover of religion merely to express their political protest (Coleman 2005: 158). The theory was that once the old regime was defeated, freedom and happiness could be built on earth. Believing in the power of the Bolshevik message (content), he had before the revolution even proposed to use the Christian language (form) more widely when explaining Marxist concepts on morality to the peasants (Williams 2001: 82). In addition to that, many Bolsheviks - being fascinated by the efficiency of the hardworking and cooperative spirit among sectarians - encouraged them to establish collective farms (Etkind 2003; Savin 2004). They seemed to be "the Christian proletariat" and a good example for the rest of the country (see also Nikol'skaia 2009: 6692).

Looking closer at the relational dynamics of Communists and sectarians is instructive for understanding how important imitation and especially accusations of imitation were in that period. The 1920s saw a widespread mirroring 
between Christians and Communists from various angles that created unavoidable distortions. Misrepresentations though were often deliberate. While the Bolsheviks' language was filled with Christian imagery and metaphors, either disguised or not (cf. e.g. Kharkhordin 1999), so the Protestants' language was not entirely free from Communist revolutionary motifs either. Some Baptists called their central organization "Ispolkom", that is a Soviet acronym denoting an "executive committee". Although this kind of mimicking was certainly not practiced by all evangelicals, these examples gave the authorities a good pretext to construct the image of Baptists as serious competitors who imitated the Bolsheviks' agenda. Communists in the press nicknamed the Baptists youth organisations "Bapsomol" or "Khristomol" (from the acronym "Komsomol", i.e. the Young Communist League) which portrayed evangelicals as cunningly stealing "successful" methods from the party (Coleman 2005: 199; Savin 2004: 63-64).

Iaroslavskii who led this accusatory campaign did not share Bonch-Bruevich's view and instead supported harsher measures towards sectarians (Savin 2004: 36-37). He considered imitation dangerous. In this context, an example he gave was about a Baptist meeting in Siberia where an evangelical song was sung to the melody of the "Internationale" and the lyrics contained motifs from the Communist revolutionary anthem. Calling it an "Evangelical Internationale", he concluded: "The religion attempted to meet the demands of masses" (Iaroslavskii 1922: 140-141; cf. also Coleman 2005: 199, 270 n. 5). It is not clear how widespread these revolutionary feelings among believers were. Yet they served as perfect opportunities for making accusations. One of these accusations was that they diverted the "masses", especially the youth, from the path of the socialist construction by means of copying party methods and thus creating a parallel society (Coleman 2005: 209-211; Savin 2004: 62-64). Accusations of copying were a means in an ideological campaign against sectarians who threatened to hinder the creation of a new Soviet person and society, or in other words, their own programme of conversion. The idea that it was possible to come to exercise power over the proletariat by copying Communist methods (especially the organizational form and not content) yet seems to confirm the power of mimesis in the Bolsheviks' thinking.

Although the Orthodox were less assertive than Protestants in defending their positions, there were many of those who were ready to adapt themselves to the new ideology inside the Orthodox Church. In 1922, the Soviet authorities, by supporting an existing schismatic movement in the Church, helped into power "Renovationists" (obnovlentsy). These so-called red priests, managed by Bolsheviks, adopted the language of class conflict in order to demonstrate their allegiance to the power (Roslof 2002). Although the Renovationists' 
success remained short-term, this episode (alongside the attack against the Patriarch Tikhon) marked a beginning of the period of deepening crisis inside the ROC. A real crisis for all Christians arrived at the end of the decade with the beginning of the Stalinist cultural revolution in 1928. Virtually all religious unions were shut down by the mid-1930s. Attempts to convert believers into Communists were replaced by destroying them. At the same time, the proportion of Christians in the population had not decreased significantly, despite Stalin's objective to eradicate religion completely by 1937 (Walters 1993: 15).

\section{PRIMITIVE COMMUNISTS OR COMMUNIST PRIMITIVES?}

In the eyes of the state northern indigenous peoples were quite a different case compared to various kinds of Christians. They were seen as promising raw material that could be shaped into new Soviet men and women through an accelerated civilizing process. When the so-called Committee of the North was formed in 1924 in order to manage the northern natives, debates about the integration of the northerners into the broader society became common (Slezkine 1994) ${ }^{5}$. The members of the Committee were convinced that indigenous reindeer herders, hunters and fishermen lived in classless groups. They were seen as "primitive communists" who in their primitiveness did not exploit each other (exploiters in the North were Russian old settlers, American traders and other "capitalists"). Natives had to be taught first the significance of the October Revolution and the central role of its leader Lenin. Using widely the expertise of ethnographers, the Committee despatched to the tundra and taiga "missionaries of the new culture and of Soviet statehood", as a wellknown anthropologist Bogoraz put it (Bogoraz-Tan 1925a: 48). Enthusiastic ethnographers educated by Shternberg were sent to the North for surveying what was out there and for teaching the doctrines of Marxism-Leninism and civilization to the Siberian aborigines. In practice it turned out to be no simple task. Once in the tundra or taiga, they met similar difficulties to their Orthodox predecessors ranging from cold and hunger to the enmity of the Russian old settlers (Grant 1995; Leete 2005a; Slezkine 1994; Ssorin-Chaikov 2003).

Both Protestants and the northern peoples came to occupy a somewhat ambiguous place in the (divided) imagination of leading state ideologists of the 1920s. From their point of view both sectarians and northern natives could be sympathised with to a certain extent because they had suffered during the old regime. Also they were considered "natural" socialists (or Communists), as they had no class division in their ranks (a position that was revised in the late 1920s). And yet they were seen as misguided or ignorant and therefore in need 
of (re-)education. Illiterate natives had not received any formal education before except for a few. Sectarians who were more often literate (thanks to their everyday Bible reading) than party officials, could not be represented as uneducated. Challenges of converting these two minorities were thus different. Unlike the northern peoples, evangelicals could be approached without difficulty, as they were seen everywhere, even on the banks of the Moskva River where they performed baptisms. The problem was that the Protestants did not want let to go their beliefs despite the systematic efforts of the state-managed League of the Godless (Peris 1998). Because of their "stubbornness", the hostility of the authorities towards them was growing.

In 1928, the protectionist policy towards indigenous northerners started to disappear, as the Committee of the North had to align with the cultural revolution. Northerners were facing the acceleration of time and a leap from the Stone Age to socialism within ten years (Grant 1995: 9-10; Slezkine 1994: 220, 265). With the introduction of an ideology for total class struggle, the earlier, natural, gradual development of small northern peoples was replaced by a programme of enforced transformation. Widespread protectionist calls such as not equating shamans with priests (e.g., Leonov 1929: 226) were no longer published in periodicals. The other way around, now shamans became equated with priests and declared to be exploiters alike and thus subject to punishment under the law (Skachkov 1934). They were taxed, expelled from the local "native councils" (tuzemnye sovety) and their regalia taken away. Some were just arrested or shot, others managed to stay hidden, concealing their practices or turning them into artistic performances (Leete 2005b: 59; Slezkine 1994: 226 228; Vitebsky 2005: 231-255).

Thus in the 1930s, as mentioned above, the Orthodox clergy, the members of Protestant churches and the shamans were categorized as "the enemies of the people". Ordinary people who had been allegedly duped by the believers had to be shown the light of the scientific truth and their false idols had to be destroyed. For example, Soviet officials and police were sent to the tundra to confiscate shamans' drums, statues of spirits and other items definable as "religious". They repeated what they had done in the South where they shot icons in order to show that God did not punish them (Brovkin 1998: 94). The Nenets in the Bolshezemelskaya tundra, still seventy years later, tell a story how a "Russian communist" came to a reindeer herders' camp and asked to see an image of the female spirit of the tent. In order to prove the figure's "mere materiality", he took a rifle and shot it. But the bullet bounced back and killed the Russian (see also Vallikivi 2009). Similar stories are numerous from all over Siberia. 
Bearing in mind changes over the time in power relations, we shall next focus on the case of the Naukan Yup'ik who became a part of the ideological battle for minds. The results were sometimes quite unexpected.

\section{TRANSFORMATIONS AMONG NAUKAN YUP'IK MARITIME HUNTERS}

In the coastal village of Naukan (Nuvuqaq) on the East Cape (Dezhnev), the north-easternmost point of Asia, the local Yup'ik Eskimo community became home for a heightened ritual activity in the early 1930s (especially 1932-33). Anthropologists Golovko and Schweitzer carried out an interview with a Naukan Eskimo called Nikolay Ivanovich Yaken in 1993. From that we learn that in Yaken's childhood two local men called Nunegnilan and Kantaggun and a woman called Aminak organised gatherings and performed rituals inspired by Christianity. Nunegnilan was known to be a shaman who then became a pop ('priest'), the name that Yaken attributed to all three. They came together on Sundays in a tent (yaranga) and invited people to participate in these gatherings. The popy (the plural for pop) wore black gowns with wide long sleeves and selfmade crosses hung on their chests. One of the popy who had a white handkerchief in his hands went around in the yaranga and muttered something. After "talks" dances were performed. According to Yaken, one third of the village was engaged in this new ritual activity. The popy did not go and hunt for themselves but the "people who believed in them" brought meat and blubber to them. They did not allow their children to attend school. "They hated those who attended school," recalls Yaken who was then a schoolboy himself. They also spoke against washing with soap. Yet not all in the village shared their feelings and there were those who opted for relations with the Soviet Russians. Yaken claimed that "everybody" respected his brother. As a proof, he said: "When the [Russian] chief border guard came to Naukan, he stayed at my brother's yaranga". Yet the popy disliked his brother because of his close relationship with the Russians. When his brother visited a Sunday ritual carried out by the popy, one of them noticed him and said: "Oh, I feel dizzy; I can feel the Russian smell. Kick him out" (Golovko \& Schweitzer 2006: 102-103; Schweitzer \& Golovko 2007: 40; see also Leete \& Vallikivi 2011). ${ }^{6}$

Naukan villagers had tight kin and trade contacts with Iñupiaq (later increasingly more mixed with Yup'ik) island communities on the Big and Little Diomede (across the Russian/Soviet-US border) and Iñupiaq Eskimo coastal settlements on the Seward Peninsula in Alaska. Asiatic Eskimos travelled to Alaska often in order to exchange fox pelts, old ivory and other local raw mate- 
rials for food, rifles, clothes and other modern commodities that were scarce on the Russian side (Schweitzer \& Golovko 1995, 1997). Also in the second half of the 19th century, American whalers became very active in the area and some from Naukan even worked on these ships (Schweitzer \& Golovko 2007: 40).

American Eskimo settlements had attracted Yup'ik Eskimos already in the pre-Soviet period for various demographic and economic reasons (cf. Krupnik 1994: 69). Yup'ik and Iñupiaq communities were going through a significant demographic change since the late 19th century. Krupnik writes that there was a steady eastward drift. By 1930, almost all Iñupiaq-speaking Big Diomeders had moved to Little Diomede from where people moved to the Alaskan mainland. Yup'ik-speaking Naukan villagers settled on Big Diomede and Little Diomede. Krupnik gives as a reason for this chain-migration as better economic conditions on the American side and the restoration and viability of the communities (Krupnik 1994: 63).

Economic conditions of the Chukchis, Yup'ik Eskimos and Koryaks were relatively satisfactory by the end of the tsarist period mainly due to foreign trade (Bogoraz-Tan 1925b: 29; Bonch-Osmolovskii 1925: 81-82). During the 1920 s, the American economic influence on Chukotka was growing even more. After the First World War, these regions were cut off from the Russian mainland and they were supplied almost exclusively by American, Japanese and other traders (Kuftin 1925: 67; Bonch-Osmolovskii 1925: 83-84, 86-89; Istoria Chukotki 1989: 156-158; Orlova 1999: 21). The Communists were aware of the attraction of the US, as pointed out above. In their civilizing mission, the Soviets attempted to improve the material side of the Yup'ik life but the success was minimal.

The import of foreign goods to the Far East was even supported by the Soviet authorities in the early years of Soviet statehood. In 1923, Dalrevkom ${ }^{7}$ provided a right to the British company Hudson Bay to supply tax-free to Chukotka and Kamchatka in order to challenge the domination of companies from the US and Japan. In 1929, the Committee of the North complained that the Soviet state was still not able to supply goods for Chukotka (Gurvich 1987: 19; see also Vasil'ev \& Tugolukov 1987: 62; Istoria Chukotki 1989: 169).

Yet we can see the contradictory nature of the Soviet policies similar to the one with the Protestants we have discussed above. Local Soviet officials attempted to discredit and "unmask" the American traders, as we can see from the report of the secretary of Dalrevkom G. G. Rudykh, written in the early 1920s:

We told a hunter that traders cheated them, paying too little for furs. But he answered: 'Give us more and provide things that we really need. 
Then I can sell everything to you.' But we could not give him anything because we had no goods at all (Borba 1967: 135).

While visiting Chukotka in 1924, Knud Rasmussen describes his experience with a Chukchi man "who spoke a few words of English" and who was interested in doing business with him "somewhere out of sight along the shore". Rasmussen insisted that he wanted to conform to the law, but the man "protested, urging that the shops were all empty, and one could not even purchase ammunition." Rasmussen then refers to a case when a trader from the American side came to barter on Chukotka but was seized and fined before being released (Rasmussen 1927: 364).

As it appears from these sources, the Yup'ik Eskimos were tightly integrated into the overseas economic and religious networks. Although the Soviet reforms (including attempts to restrict communication between the Siberian Yup'ik and foreigners) had predominantly materialistic and secular aims, several unexpected spiritual outcomes accompanied the introduction of the new statehood.

As we saw above, from the indigenous perspective, certain changes had been thought to cause undesired spiritual consequences. Naukan popy reacted against the Soviet policies, especially their divisive attempts to change social relations in the village, collectivise their items and manage their bodies (see also Leete \& Vallikivi 2011). For instance, the resistance against washing with soap can be seen as a reaction against intrusive politics of the human body which from the native point of view can be a major focus of the change (see Vilaça \& Wright 2009). Wearing underwear, washing hands regularly, weekly visits to sauna and the cutting of hair became a mandatory part of everyday life. Soviet ethnographer Menovshchikov reports cultural-enlightening stepby-step victories over the Asiatic Eskimos who "never washed themselves" (1959: 135). A special programme was launched by teachers and doctors at the beginning of the 1930s to accustom natives to wash their faces and hands, also to cut their hair. "In the beginning before coming to school, children washed themselves with urine that created an unbearable smell in the classroom for an unaccustomed person. Then an obligatory washing at school in the mornings was introduced" (Menovshchikov 1959: 136). Special sanitary commissions were created that worked in the village councils and the Komsomol was called in for the fight against filth, the major sign of the backwardness of the natives.

In many ways this was similar to what missionaries and teachers did on the American side (cf. Berardi 1999). There in various locations they met considerable resistance, especially from local shamans (Fienup-Riordan 1991: 76, 119 $120)^{8}$. Nyseters, a Lutheran missionary couple, describe a situation of an Eskimo man falling ill with tuberculosis on Little Diomede: 
Encouraged by his wife and mother-in-law, he expressed a desire to know the Lord. Not recovering immediately, he resorted to witchcraft - giving his gun as advance payment. His family, until then one of the cleanest in the community, cooperated by subjecting themselves to a long list of rules such as don't bathe, don't comb your hair, and don't work. Of course these didn't help. Finally Elasanga asked to be carried over to the other island, possibly because a shaman works better without opposition (Rodli 1999: 118-119).

Both Christian missionaries in Alaska and Soviet Communists on Chukotka executed their civilising mission by imposing a regime of exclusivity and hierarchy. But the way they did it and how they succeeded in it were significantly different. As most sources confirm, what likely mattered the most for the Naukan villagers was the abundance of cargo in America. It can be argued that it was a logical step to relate the presence of the missionaries with this abundance. The Soviets were not able to offer the material exchange because of the lack of goods. Material and spiritual is hard to disentangle from each other, especially from the viewpoint of the indigenous population for whom the distinction did not exist in this neat way. The sources we have seem to confirm that in the eyes of the Naukan Yup'ik popy acquiring commodities must have depended on Christian spirits and successful imitation of priestly actions.

\section{DISCUSSION}

A wider point that can be made is that in a colonial encounter of the kind as described above there are limits to permeability and receptivity in otherwise permeable and receptive indigenous communities. Especially when the pressure is understood to jeopardise existing social and religious forms of relatedness, boundary drawing between the "us" and "them" can become central. We would propose that the colonial pressure from the outside relied on boundary maintenance and thus compelled to imitate similar boundary practices by natives. This became the case especially in the early 1930s when the class enemy campaign against the kulaks and shamans was launched. Sources from all over Siberia show that collectivization, schooling, new rules of hygiene caused significant stress and resistance among indigenous groups (Leete 2005a). Despite "an active dissemination of scientific knowledge" and "atheistic propaganda by State and party workers, teachers, and health workers against the reactionary essence of shamanism and its harmful effects upon people's consciousness" (Tein 1994: 124, emphases are ours), conversions to Communism had to rely largely on repressive methods. It was not so much a matter of the institutions themselves than the "imposed choice" which drove many locals to 
become defiant. The Soviet practices of exclusivity were introduced without much space for manoeuvring and as a result organised resistance emerged here and there all over Siberia. Often it took some form of ritual intensification, based either on non-Christian practices (Leete 2005a; Vallikivi 2005: 3941) or Christian ones, as discussed here.

In our earlier joint study (Leete \& Vallikivi 2011) we concentrated on the pattern of imitation that can be observed in cases of indigenous re-ritualisation in the early Soviet period. In this article, we want to stress a few other things to clarify some aspects of indigenous adaptation to economic, political and religious changes through imitating dominant social actors. The appropriation of Christianity can be seen as a form of resistance. Copying can be highly creative, or as Jebens has put it, imitation can be conceptualised as an "active mimetic appropriation" (Jebens 2004: 166). This explanation echoes Taussig's account of the Amerindian Cuna imitating the Europeans by carving figurines of the whites (Taussig 1993: xiii). What Taussig's account however lacks is how the Cuna protected themselves from being completely absorbed by the Other. Santos-Granero writes about the Peruvian Yanesha:

Through the act of copying, the copyist becomes the Other in the act of making or enacting that which is being copied. Mimesis is not about erasing the frontiers between Self and Other but about redressing the power inequalities that exist between both. This can be achieved only by temporarily turning into the Other to appropriate the Other's powers. Once this objective is achieved, the mimetic agent goes back to being $\operatorname{Self}(2009: 487)$.

The intruding Soviets were managing a border with natives who took the practice over and thus became the Other in some sense. To put it differently, the new kind of border management itself became mimicked.

Certainly, the model of imitation does not cover all factors that shape the multi-directional course of a dialogic change in remote indigenous communities. Religious changes are part of larger developments in any society. As Bellah (1970: 64) has noticed some time ago, modernisation always involves some problems of a religious nature. After entering into closer contact with the modern world, indigenous societies must handle a certain identity crisis linked, according to their worldview, to the realm of the spirits. Soviets themselves emphasised some links between their materialistic reforms and Siberian indigenous groups' spiritual world (introducing of scientific medicine was targeted, besides improving people' health, against the influence of shamans). But many people in Siberia treated also the other Soviet reforms as a kind of spiritual attack.

We can conclude that changes in the Yup'ik worldview indicate several extreme social outputs during the first decades of the Soviet period. People were 
troubled and intimidated by the large scale of changes, applied by the Soviets in different spheres of life. Often these official reforms had a violent character and, at the same time, local people could not understand the general idea that initiated these reforms. In such conditions it made sense to turn towards religious ideas and practices of a new kind, potentially more transcendent ones. Material pressure from the official Soviet side actualised religious feelings in different forms among the Siberian indigenous and non-indigenous groups. This is something that is often overlooked while analysing complex processes of sociocultural change during transitional or liminal periods.

\section{NOTES}

1 This research was supported by the European Union through the European Regional Development Fund (Centre of Excellence in Cultural Theory CECT) and the Estonian Science Foundation project nr 8335.

${ }^{2}$ Yurta - skin tent of the Chukchis and other northern peoples of Russia.

${ }^{3}$ Bonch-Osmolovskii's description of the Alaskan indigenous peoples' situation does not correspond to the reality. But this approach illustrates the idea, perhaps, shared by the Soviet ideologists, that in the US the native peoples' needs were taken into account more than in the USSR.

${ }^{4}$ Knud Rasmussen documented the same situation during his short visit to Chukotka in 1924: "Until the American Bureau of Education commenced work in Alaska, the Siberian Eskimos were greatly superior to the American, both in conditions of life and in general estimation; now, however, the reverse is the case, and those Siberian natives who have been to Nome for trading purposes marvel at the enormous progress made by their fellows on that side, while they themselves live in a country whose government seems to take no interest in them whatever beyond getting their furs at the lowest possible price" (Rasmussen 1927: 378).

${ }^{5}$ Its full name was the Committee for Assistance to the Peoples of the Northern Borderlands of the All-Soviet Central Executive Committee of the USSR. It was active until 1936.

6 Among the Koryaks of the Karaginski district a semi-revitalistic movement also occurred. The situation in the region developed into a crisis when the 1927 catch of salmon around the coast was too poor. Indigenous communities could not fulfil the state plan for fish. The Koryak shaman called Savva declared that the spirits were angry and aimed to punish those who had abandoned the ancestors' traditions. To avoid this, one needed to give up the Russian clothes, stop visiting the sauna, consuming Russian food or have any relationship with Russians. Savva succeeded to convince many local Koryaks. Conflicts began to occur between the Koryaks and the local administration. The sauna was destroyed. Some Koryaks, that continued to communicate with the Russians, were forced to leave the settlement. Similar accidents occurred in other Koryak villages too. The problem of spreading the anti-Russian movement was discussed in the Congresses of the Soviets at district and regional levels (Istoria 1993: 212-213). Unfortunately, we do not have any information concerning the further development of the Koryak movement. 
7 Dalrevkom is the acronym for the 'Far Eastern Revolutionary Committee' in Russian.

${ }^{8}$ Fienup-Riordan quotes missionary Edith Kilbuck, a Moravian missionary in Kuskokwim River Valley, Alaska, in the late 19th century: "The gospel of service is the gospel that wins... So hand and hand with the message of salvation went the duties of teaching better living here and now. Better homes, better food, better clothes, the use of soap, and water, and washtubs of dishes and spoons and knives and forks - of individual cups and towels - of reading and writing and singing and playing - of marriage and fidelity and the training of children - and the hundred and one things that go to make up the life of us all" (Fienup-Riordan 1991: 76).

\section{REFERENCES}

A Collection $1919=$ A Collection of Reports on Bolshevism in Russia. Presented to Parliament by Command of His Majesty. April 1919. Russia. No. 1. London: His Majesty's Stationery Office.

Bellah, Robert N. 1970. Beyond Belief: Essays on Religion in a Post-Traditional World. New York, Hagerstown, San Francisco, London: Harper \& Row.

Berardi, Gigi 1999. Schools, settlement, and sanitation in Alaskan native villages. Ethnohistory, Vol. 46, No. 2, pp. 329-359.

Bogoraz-Tan, V. G. 1925a. Podgotovitel'nye mery k organizatsii malykh narodnostei. Severnaia Aziia, Vol. 3, pp. 40-50.

Bogoraz-Tan, V. G. 1925b. K voprosu o priroste severo-sibirskikh tuzemnykh plemen. Severnaia Aziia, Vol. 4, pp. 27-29.

Bonch-Osmolovskii, A. 1925. Kamchatsko-Chukotskii krai. Severnaia Aziia, Vols. 1-2, pp. 77-89.

Borba 1967 = Bor'ba za vlast' sovetov na Chukotke (1919-1923 gg.). Sbornik dokumentov i materialov. Magadan: Magadanskoe knizhnoe izdatel'stvo.

Brovkin, Vladimir 1998. Russia after Lenin: Politics, Culture and Society, 1921-1929. London, New York: Routledge.

Burch, Ernest 1994. The Iñupiat and the christianization of Arctic Alaska. Études/ Inuit/Studies, Vol. 18, Nos. 1-2, pp. 81-108.

Cannell, Fenella 2006. Introduction: The Anthropology of Christianity. In: F. Cannell (ed.) The Anthropology of Christianity. Durham: Duke University Press, pp. 1-50.

Coleman, Heather J. 2005. Russian Baptists and Spiritual Revolution, 1905-1929. Bloomington and Indianapolis: Indiana University Press.

Etkind, Alexander 2003. Whirling with the Other: Russian populism and religious sects. The Russian Review, Vol. 62, No. 4, pp. 565-588.

Fienup-Riordan, Ann 1991. The Real People and the Children of Thunder: The Yup 'ik Eskimo Encounter with Moravian Missionaries John and Edith Kilbuck. Norman: University of Oklahoma Press.

Golovko \& Schweitzer 2006 = Golovko, E. V. \& P. Shvaittser. Eskimosskie "popy" poselka Naukan: ob odnom sluchae revitalization movement na Chukotke. In: Zh. V. Kormina \& A. A. Panchenko \& S. A. Shtyrkov (eds.) Sny Bogoroditsy: Issledovaniia po antropologii religii. Sankt-Peterburg: Izdatel'stvo Evropeiskogo universiteta v Sankt-Peterburge, pp. 102-115.

Grant, Bruce 1995. In the Soviet House of Culture:A Century of Perestroikas. Princeton: Princeton University Press. 
Gurvich, I. S. 1987. K sotsializmu, minuia kapitalizm. In: I. S. Gurvich (ed.) Etnicheskoe razvitie narodnostei Severa v sovetskii period. Moskva: "Nauka”, pp. 11-31.

Iaroslavskii, Emelyan 1922. Po Sibiri. (Vnutrennee obozrenie). Sibirskie ogni, No. 3, pp. $132-145$.

Istoria 1993 = Istoriia i kul'tura koriakov. Editor in chief A. I. Krushanov. Sankt-Peterburg: Nauka.

Istoria Chukotki 1989 = Istoriia Chukotki s drevneishikh vremen do nashikh dnei. Editor in chief N. N. Dikov. Moskva: "Mysl".

Jebens, Holger 2004. Talking about cargo cults in Koimumu (West New Britain Province, Papua New Guinea). In: H. Jebens (ed.) Cargo, Cult, and Culture Critique. Honolulu: University of Hawai'i Press, pp. 157-169.

Jolles, Carol Zane 1989. Salvation on St. Lawrence Island: Protestant conversion among the Sivuqaghhmiit. Arctic Anthropology, Vol. 26, No. 2, pp. 12-27.

Kerttula, Anna M. 2000. Antler on the Sea: the Yup'ik and Chukchi of the Russian Far East. Ithaca and London: Cornell University Press.

Kharkhordin, Oleg 1999. The Collective and the Individual in Russia: A Study of Practices. Berkeley: University of California Press.

Krupnik, Igor 1994. 'Siberians' in Alaska: The Siberian Eskimo contribution to Alaskan population recoveries, 1880-1940. Études/Inuit/Studies, Vol. 18, Nos. 1-2, pp. 49-80.

Kuftin, B. A. 1925. Melkie narodnosti i etno-kul'turnye vzaimootnosheniia na severovostoke Sibiri. Severnaia Aziia, Vols. 1-2, pp. 63-89.

Leete, Art 2005a. Anti-Soviet movements and uprisings among the Siberian indigenous peoples during the 1920-40s. In: A. Leete \& Ü. Valk (eds.) The Northern Peoples and States: Changing Relationships. Studies in Folk Culture, Vol. 5. Tartu: Tartu University Press, pp. 55-89.

Leete, Art 2005b. Religious revival as reaction to the hegemonization of power in Siberia in the 1920 s to 1940 s. Asian Folklore Studies, Vol. 64, No. 2, pp. 233245.

Leete, Art \& Vallikivi, Laur 2011. Imitating enemies or friends: Comparative notes on Christianity in the indigenous Russian Arctic during the early Soviet period. Asian Ethnology, Vol. 70, No. 1, pp. 81-104.

Leonov, N. I. 1929. Tuzemnye sovety v taige i tundrakh. Sovetskii Sever, No. 1, pp. 219-258.

Mel'nikov, V. I. 1925. K voprosu o pomoshchi brodiachim i kochevym narodnostiam. (Pis'mo iz Iakutska). Severnaia Aziia, Vols. 5-6, pp. 160-164.

Menovshchikov, G. A. 1959. Eskimosy. Nauchno-populiarnyi istoriko-etnograficheskii ocherk ob aziatskikh eskimosakh. Magadan: Magadanskoe knizhnoe izdatel'stvo.

Nikol'skaia, Tat'iana 2009. Russkii protestantizm i gosudarstvennaia vlast'v 19051991 godakh. SPb: Izdatel'stvo Evropeiskogo universiteta v Sankt-Peterburge.

Orlova, E. P. 1999. Itel'meny. Istoriko-etnograficheskii ocherk. Sankt-Peterburg: Nauka.

Peris, Daniel 1998. Storming the Heavens: The Soviet League of the Militant Godless. Ithaca: Cornell University Press.

Rasmussen, Knud 1927. Across Arctic America: Narrative of the Fifth Thule Expedition. New York: G. P. Putnam's Sons.

Robbins, Joel 2009. Afterword. In: A. Vilaça \& R. M. Wright (eds.) Native Christians. Modes and Effects of Christianity among Indigenous Peoples of the Americas. Farnham: Ashgate, pp. 229-238. 
Rodli, Agnes 1999. Strait Gate. A Norse Saga: Mission to the Diomede Islands in the 1920s. Enumclaw: WinePress Publishing.

Roslof, Edward 2002. Red Priests: Renovationism, Russian Orthodoxy, and Revolution, 1905-1946. Bloomington: Indiana University Press.

Santos-Granero, Fernando 2009. Hybrid bodyscapes: A visual history of Yanesha patterns of cultural change. Current Anthropology, Vol. 50, No. 4, pp. 477-512.

Savin, A. I. 2004. Sovetskoe gosudarstvo i evangel'skie tserkvi Sibiri v 1920-1941 gg. Dokumenty i materialy. Novosibirsk: Posokh.

Schweitzer, Peter \& Golovko, Evgeniy 1995. Traveling between continents: The social organization of interethnic contacts across Bering Strait. Anthropology of East Europe Review, Vol. 13, No. 2, pp. 50-55.

Schweitzer, Peter \& Golovko, Evgeniy 1997. Local identities and traveling names: Interethnic aspects of personal naming in the Bering Strait area. Arctic Anthropology, Vol. 34, No. 1, pp. 167-180.

Schweitzer, Peter \& Golovko, Evgeniy 2007. The "priests" of East Cape: A religious movement on the Chukchi Peninsula during the 1920s and 1930s. Études/Inuit/ Studies, Vol. 31, Nos. 1-2, pp. 39-58.

Skachkov, I. F. 1934. Antireligioznaia rabota na Krainem Severe. Moskva: OGIZ, Gosudarstvennoe antireligioznoe izdatel'stvo.

Slezkine, Yuri 1994. Arctic Mirrors: Russia and the Small Peoples of the North. Ithaca: Cornell University Press.

Ssorin-Chaikov, Nikolai 2003. The Social Life of the State in Subartic Siberia. Stanford: Stanford University Press.

Taussig, Michael 1993. Mimesis and Alterity: A Particular History of the Senses. New York: Routledge.

Tein, Tassan S. 1994. Shamans of the Siberian Eskimos. Arctic Anthropology, Vol. 31, No. 1, pp. 117-125.

Vallikivi, Laur 2005. Two wars in conflict: Resistance among Nenets Reindeer herders in the 1940s. The Northern Peoples and States: Changing Relationships. Studies in Folk Culture, Vol. 5, pp. 14-54.

Vallikivi, Laur 2009. Christianization of words and selves: Nenets reindeer herders joining the state through conversion. In: M. Pelkmans (ed.) Conversion After Socialism:Disruptions, Modernities and the Technologies of Faith. Oxford: Berghahn Books, pp. 59-83.

Vasil'ev, V. I. \& Tugolukov, V.A. 1987. Natsional'no-gosudarstvennoe stroitel'stvo, sotsialisticheskoe pereustroistvo khoziaistva, byta i kul'tury i etnicheskie protsessy (1917-1940 gg.). In: I. S. Gurvich (ed.) Etnicheskoe razvitie narodnostei Severa $v$ sovetskii period. Moskva: Nauka, pp. 62-90.

Vilaça, Aparecida \& Wright, Robin M. (eds.) 2009. Native Christians: Modes and Effects of Christianity among Indigenous Peoples of the Americas. Farnham: Ashgate.

Vitebsky, Piers 2005. Reindeer People: Living with Animals and Spirits in Siberia. London: HarperCollins.

Walters, Philip 1993. A survey of Soviet religious policy. In: S. P. Ramet (ed.) Religious Policy in the Soviet Union. Cambridge: Cambridge University Press, pp. 3-30.

Williams, Robert C. 2001. Orthodoxy and eschatology in post-Bolshevik culture. Kritika: Explorations in Russian and Eurasian History, Vol. 2, No. 1, pp. 81-86. 